\title{
OPTIMASI PEMBUATAN FURFURAL DARI TEMPURUNG KEMIRI (Aleurites moluccana) MELALUI HIDROLISIS ASAM
}

\section{FURFURIC ACID SYNTHESIS OPTIMASATION OVER ACIDIC HYDROLYSIS OF CANDELNUTSHELL (Aleurites moluccana)}

\author{
Maria Angelina Tuas ${ }^{* 1)}$ dan Reinner I. Lerrick ${ }^{1)}$ \\ ${ }^{1)}$ Jurusan Kimia, Universitas Nusa Cendana, \\ Jl. Adi Sucipto Kampus Baru, Penfui Kupang \\ ${ }^{*}$ E-mail: angeltuas@yahoo.com
}

\begin{abstract}
Abstrak
Telah dilakukan penelitian tentang pembuatan furfural dari tempurung kemiri melalui hidrolisis asam. Penelitian ini bertujuan untuk optimasi pembuatan furfural melalui hidrolisis pentosan tempurung kemiri. Tahap penelitian meliputi preparasi sampel, pembuatan furfural dengan metode refluks disertai variasi katalis dan waktu pemanasan, pembuatan furfural metode destilasi dan analisis spektroskopi. Hasil penelitian menunjukkan bahwa kemurnian furfural yang diperoleh sebesar 99,88\% pada kondisi optimum 30\% asam sulfat dan direfluks selama 5 jam.
\end{abstract}

Kata kunci: furfural, hidrolisis asam, pentosa, spektroskopi, tempurung kemiri.

\begin{abstract}
This research aimed to optimize the production of furfural by acid hydrolysis of candlenut shell pentosan. Research phases include sample preparation, furfural production with reflux with variations of concentration and heating time, furfural production with distillation, and spectroscopy analysis. It was found that furfural purity of 99,88\% was produced after the sample was refluxed under optimum conditions (30\% sulfuric acid for 5 hours).
\end{abstract}

Keywords: acid hydrolysis, candelnut shell, furfuril acid, penthose, spectroscopy.

\section{PENDAHULUAN}

Furfural banyak digunakan sebagai pelarut dalam industri pengolahan minyak bumi, bahan pembuatan pelumas, nilon, pewarna sepatu, bahan baku insektisida, herbisida dan fungisida. Furfural $\left(\mathrm{C}_{5} \mathrm{H}_{4} \mathrm{O}_{2}\right)$ murni hasil destilasi merupakan cairan beraroma harum dan tak berwarna. Beberapa saat setelah proses destilasi pemurniannya, furfural akan berubah warna menjadi coklat kehitaman saat kontak dengan udara. Furfural merupakan senyawa karsinogenik dan menyebabkan iritasi jika kontak dengan kulit atau mata. Furfural juga merupakan bahan baku dalam sintesis senyawa turunan tetrahidrofuran, furfuril alkohol, dan selulosa asetat (Juwita, 2012). Struktrul furfural dapat dilihat pada Gambar1. Kebutuhan furfural Indonesia hingga saat ini seluruhnya diperoleh melalui impor. Tahun 2011, impor furfural Indonesia dari Cina sebesar $800.121 \mathrm{~kg}$. Menurut Winaputri (2014), kebutuhan furfural Indonesia pada tahun 2017 dapat mencapai $805.626 \mathrm{~kg} /$ tahun. 


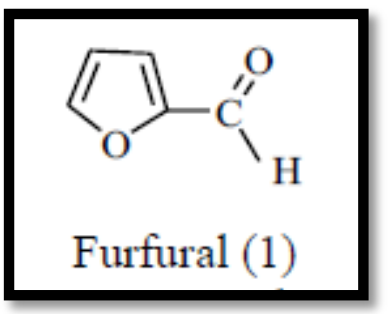

Gambar 1. Struktur furfural

Furfural (1) dapat dihasilkan dari biomassa yang mengandung pentosan (2) melalui hidrolisis dan dehidrasi terkatalisis asam. Hidrolisis pentosan (2) akan menghasilkan pentosa (3) yang diikuti proses dehidrasi membentuk furfural (1). Asam sulfat paling umum digunakan dalam proses hidrolisa karena memberikan perolehan kadar furfural yang lebih besar daripada penggunaan katalis asam klorida. Reaksi yang terjadi yakni hidrolisis pentosan menjadi pentosa yang dapat dilihat pada Gambar 2 dan dehidrasi pentosa membentuk furfural yang dapat dilihat pada Gambar 3.

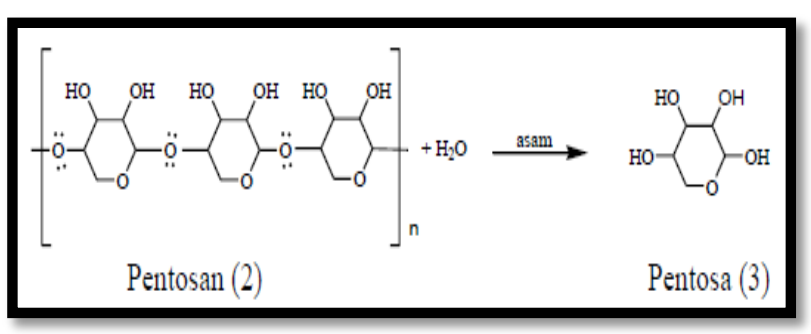

Gambar 2. Mekanisme reaksi hidrolisis pentosan menjadi pentose

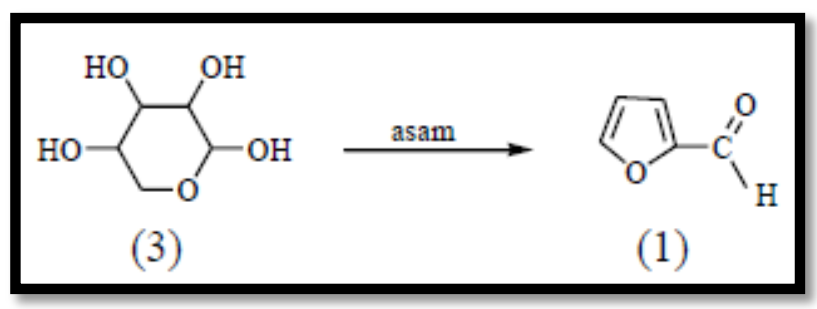

Gambar 3. Mekanisme reaksi dehidrasi pentosa membentuk furfural

Pembuatan furfural dari limbah pertanian telah dilakukan oleh beberapa peneliti diantaranya oleh Sri Mulyati dan Umi Fathanah (2008) dengan memanfaatkan limbah sekam padi, dan Andaka (2013) yang menggunakan ampas tebu. Limbah pertanian lainnya seperti tongkol jagung, alang-alang, sekam padi, kulit kacang tanah dan gandum juga telah digunakan untuk menghasilkan furfural (Panturau, 1987). Lempang (2011) mengatakan bahwa dalam tempurung kemiri terdapat $14,55 \%$ pentosan, senyawa prekursor furfural.

Kemiri (Aleurites moluccana) merupakan pohon yang banyak dijumpai dan dibudidayakan oleh masyarakat Indonesia. Propinsi Nusa Tenggara Timur memiliki luas area perkebunan kemiri mencapai 84.941 hektar, dengan produksi buah kemiri sebesar 14.625 ton/tahun (Kimbal, 1988). Tanaman kemiri hanya dimanfaatkan kayu dan biji buahnya. Limbah yang dihasilkan dari proses pemecahan biji kemiri berupa tempurung selama ini dimanfaatkan sebagai bahan baku pada pembuatan arang aktif (Lempang, 2011).

Tujuan umum penelitian ini yaitu menentukan kondisi optimum dan membuat furfural dari tempurung kemiri berdasarkan kondisi optimum yang diperoleh. Berdasarkan uraian diatas, maka dilakukan penelitian dengan yang berjudul Optimasi pembuatan furfural dari tempurung kemiri (Aleurites moluccana) melalui hidrolisis asam. Sehingga dapat meningkatkan nilai ekonomis dari limbah tempurung kemiri.

\section{METODA}

\section{Lokasi Penelitian}

Lokasi pengambilan sampel di Desa Ainiut, Kecematan Insana, Kabupaten TTU. Penelitian dilakukan di Laboratorium Kimia Analitik FST Universitas Nusa Cendana, sedangkan analisis FTIR dilakukan di Laboratorium Kimia Institut Teknologi Sepuluh November dan GCMS di Laboratorium Kimia Organik Universitas Gadjah Mada.

\section{Bahan dan alat}


Bahan-bahan penelitian yang dibutuhkan meliputi: tempurung kemiri, asam sulfat $\left(\mathrm{H}_{2} \mathrm{SO}_{4}\right)$, petroleum eter, diklorometan $\left(\mathrm{CH}_{2} \mathrm{Cl}_{2}\right)$, kertas saring, batu didih dan aquades. Penelitian dilakukan menggunakan seperangkat alat refluks dan destilasi serta analisis menggunakan spektrofotometer UVVis, GC-MS dan FT-IR.

\section{Prosedur}

\section{1) Persiapan Bahan Baku}

Tempurung kemiri dicuci dengan air, kemudian dijemur dibawah sinar matahari. Setelah kering dihaluskan dan diayak dengan ayakan 60 mesh $(250 \mu \mathrm{m})$ agar diperoleh serbuk tempurung kemiri yang homogen.

2) Penentuan Kondisi Optimum Pembuatan Furfural Metode Refluks

Penentuan kondisi optimum pembuatan furfural dilakukan pemanasan dengan memvariasikan konsentrasi $\mathrm{H}_{2} \mathrm{SO}_{4}$ dan lama waktu pemanasan. 10 gr sampel masing-masing ditambahkan $100 \mathrm{~mL}$ $\mathrm{H}_{2} \mathrm{SO}_{4}(10 \%$, 20\% dan 30\%). Penelitian Andaka (2013) memperoleh yield furfural sebasar $5,79 \%$ dengan konsentrasi asam sulfat $8 \%$, maka untuk meningkatkan perolehan furfural digunakan konsentrasi asam sulfat yang lebih besar dari $8 \%$.

Kondisi optimum konsentrasi $\mathrm{H}_{2} \mathrm{SO}_{4}$ yang telah diperoleh, digunakan dalam menentukan waktu pemanasan optimun dengan variasi 5, 10, dan 15 jam pemanasan pada suhu $107^{\circ} \mathrm{C}$. Penelitian Sry Mulyati dan Umi Fathanah (2008) dan Hidajati (2006) menghasilkan furfural sebesar 7,53\% selama 6 jam pemanasan dan $13,30 \%$ selama 3,5 jam pemanasan.

Furfural yang telah diperoleh dianalisis dengan spektrofotometer UV-Vis pada $\lambda$ $490 \mathrm{~nm}$. Konsentrasi furfural dalam sampel dapat dihitung berdasarkan kurva standar furfural murni yang diperoleh dari penelitian Tefi (2014). Furfural murni diperoleh dengan cara pemisahan melalui ekstraksi menggunakan pelarut petroleum eter dan selanjutnya dievaporasi. Sampel yang dihasilkan diidentifikasi dengan GCMS.

\section{3) Pembuatan Furfural Metode Destilasi}

Pembuatan furfural dilanjutkan dengan mengulangi menggunakan metode destilasi karena dengan metode refluks tidak diperoleh furfural yang murni. $100 \mathrm{gr}$ sampel tempurung kemiri dan $250 \mathrm{~mL}$ asam sulfat $30 \%$ didestilasi selama 5 jam pada suhu $101{ }^{\circ} \mathrm{C}$ sampai $107^{\circ} \mathrm{C}$. Furfural dan uap air akan menguap lalu terkondensasi dalam pendingin Liebig kemudian menetes masuk kedalam labu destilat yang telah terisi diklorometan. Furfural akan larut dalam diklorometan, sedangkan airnya terpisah. Diklorometan yang berada dilapisan bawah dipisahkan dengan corong pisah. Furfural dalam diklorometan dipisahkan dengan destilasi sehingga diperoleh cairan furfural murni. Diklorometan akan menguap pada suhu 40 ${ }^{\circ} \mathrm{C}$ dan tersisalah furfural. Furfural murni yang dihasilkan kemudian diidentifikasi menggunakan GC-MS dan FT-IR (Nalle, 2013).

\section{HASIL DAN PEMBAHASAN}

\section{Preparasi sampel}

Sampel tempurung kemiri yang telah bersih diayak dengan ayakan 60 mesh sehingga diperoleh sampel berukuran 60 mesh dan homogen. Ukuran sampel berpengaruh terhadap kecepatan reaksi hidrolisis. Semakin kecil ukuran partikel sampel, maka semakin luas bidang sentuh antar zat pereaksi sehingga kontak antar molekul semakin besar (Andaka, 2013). Serbuk tempurung kemiri yang diperoleh digunakan sebagai bahan dasar dalam pembuatan furfural. Tempurung kemiri dan serbuk tempurung kemiri dapat dilihat pada Gambar 4. 


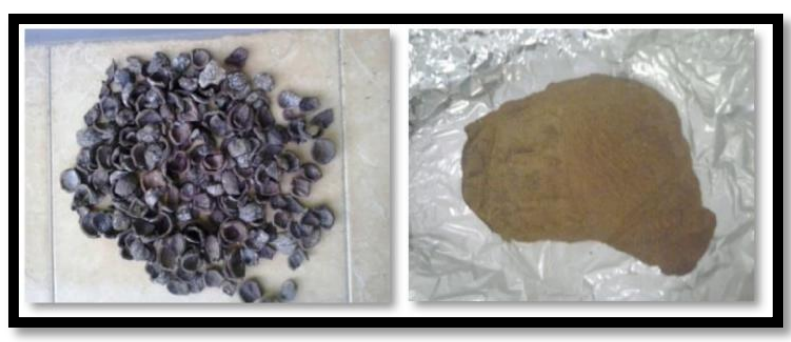

Gambar 4. Tempurung kemiri (a), dan serbuk tempurung kemiri (b).

\section{Penentuan Kondisi Optimum Pembuatan Furfural Metode Refluks}

Kondisi optimum pembuatan furfural dengan metode refluks dilakukan melalui variasi konsentrasi $\mathrm{H}_{2} \mathrm{SO}_{4}$ dan waktu pemanasan yang daat dilihat pada Gambar 5.

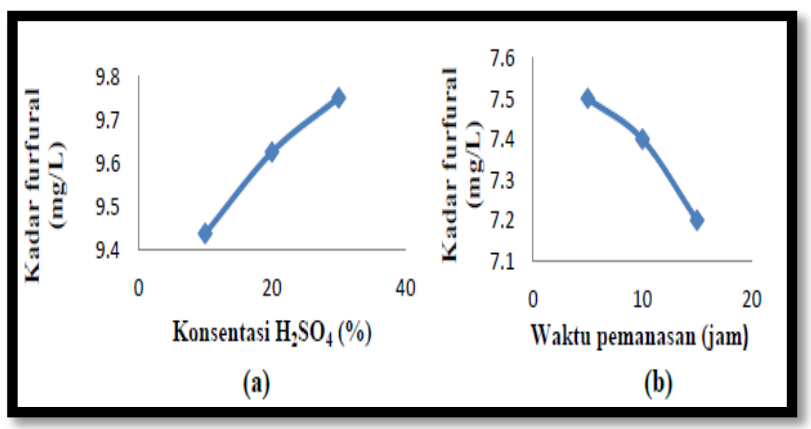

Gambar 5. Pengaruh (a) konsentrasi asam dan (b)waktu pemanasan terhadap kadar furfural

Gambar 5(a) menunjukkan bahwa terjadi peningkatan hasil furfural seiring dengan meningkatnya konsentrasi $\mathrm{H}_{2} \mathrm{SO}_{4}$. Hal ini disebabkan karena bertambahnya keberadaan jumlah ion $\mathrm{H}^{+}$dari asam sulfat, sehingga pemutusan ikatan pentosan menjadi monomer-monomernya berlangsung lebih baik, kecepatan reaksi semakin meningkat dan memberikan hasil hidrolisis yang semakin besar. Hasil penelitian juga didukung oleh Setyadji (2007) yang menunjukkan bahwa terjadi peningkatan hasil furfural sejalan dengan meningkatnya konsentrasi katalisator asam sulfat yang digunakan.
Waktu optimum pembuatan furfural dilakukan dengan menggunakan $\mathrm{H}_{2} \mathrm{SO}_{4} 30 \%$ melalui proses pemanasan pada 5 jam, 10 jam dan 15 jam. Gambar 5(b) menunjukkan bahwa perolehan kadar furfural tertinggi pada waktu pemanasan 5 jam, menghasilkan kadar furfural sebesar 7,5 ppm. Semakin lama waktu pemanasan kadar furfural semakin sedikit karena furfural yang terbentuk telah terdegradasi menjadi furan akibat pemanasan terus- menerus.

Furfural dengan kadar tertinggi yang dihasilkan melalui metode refluks kemudian diekstrak dengan petroleum eter untuk memisahkan furfural dari $\mathrm{H}_{2} \mathrm{SO}_{4}$ dan pengotor lainnya. Hasil identifikasi furfural dengan GC-MS dapat dilihat pada Gambar 6, menunjukkan adanya beberapa puncak yang merupakan senyawa furfural tetapi dengan kadar yang rendah dan tidak murni.

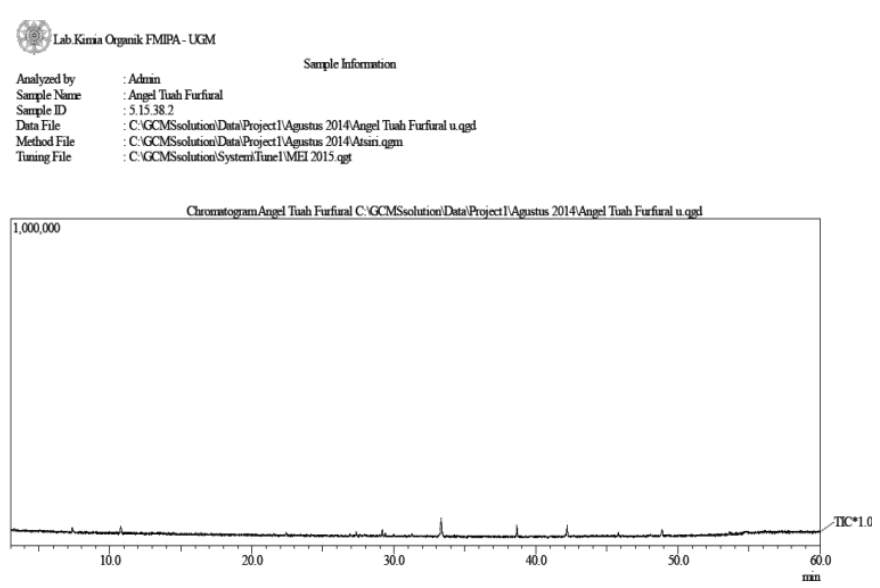

Gambar 6. Kromatogram furfural dengan metode refluks

\section{Mekanisme Pembuatan Furfural}

Proses pembuatan furfural meliputi dua tahapan utama yaitu hidrolisis dan dehidrasi. Pada proses hidrolisis terjadi pemecahan molekul besar menjadi bagian-bagian yang lebih sederhana. Bagian sederhana yang dihasilkan merupakan komponen monomer dari senyawa itu sendiri. Katalis $\mathrm{H}_{2} \mathrm{SO}_{4}$ berperan dalam menghidrolisis pentosan (2) yang terdapat dalam sempel untuk 
menghasilkan pentosa (3). Proses pemecahan molekul pentosan menjadi bentuk monomernya (pentosa) ditampilkan dalam mekanisme reaksi pada Gambar 7.

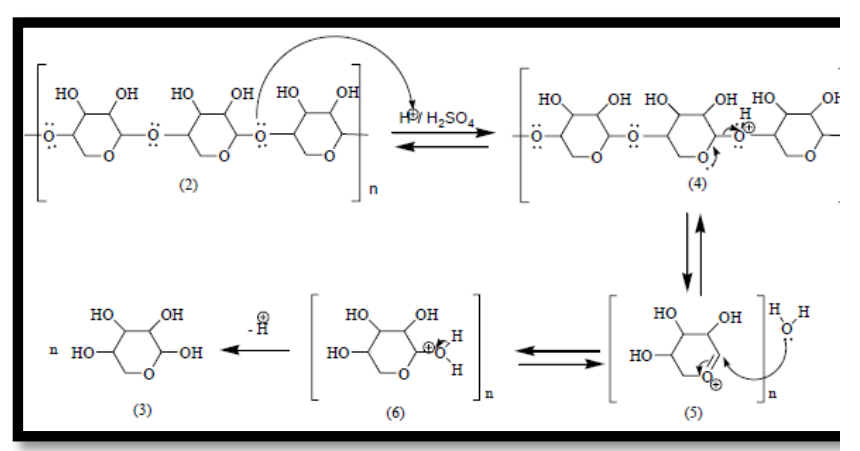

Gambar 7. Mekanisme reaksi hidrolisis pentosan menjadi pentosa
$\mathrm{H}^{+}$sebagai proton berinteraksi dengan oksigen glikosida (ikatan glikosida) yang menghubungkan monomer-monomer (2). Reaksi ini diikuti oleh pemutusan ikatan glikosida (C-O) pada (4) menghasilkan ion karbonium (5) yang selanjutnya bereaksi dengan $\mathrm{H}_{2} \mathrm{O}$ menjadi (6) dan segera mengalami deprotonasi manjadi pentosa (3). Proses selanjutnya adalah pembuatan furfural (1) dari pentosa (3) mengikuti mekanisme yang dapat dilihat pada Gambar 8 .

Pada mekanisme reaksi (Gambar 8), cincin piranosa (3) mengalami protonasi oleh $\mathrm{H}^{+}$ menghasilkan (6) yang selanjutnya mengalami dehidrasi menjadi ion karbonium (5) diikuti pembukaan cincin menjadi (7).

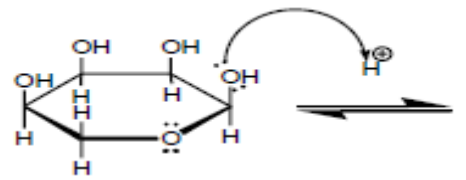

(3)

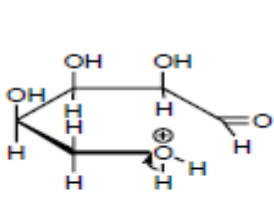

(7)

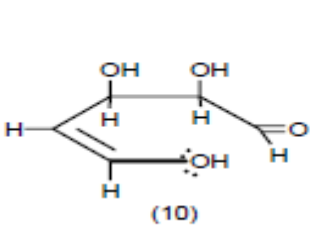

(10)

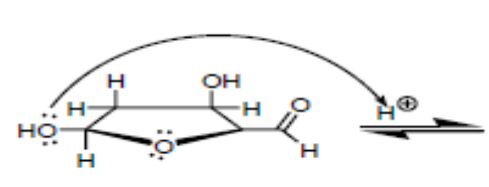

(13)

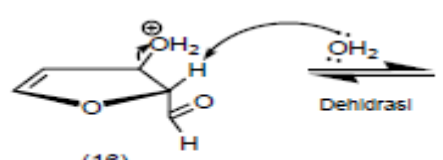

(16)

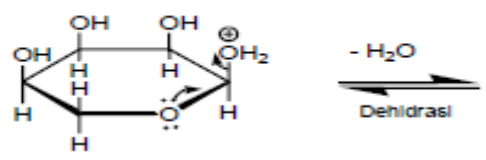

(6)

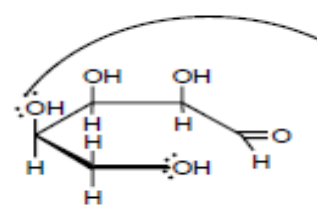

(8)
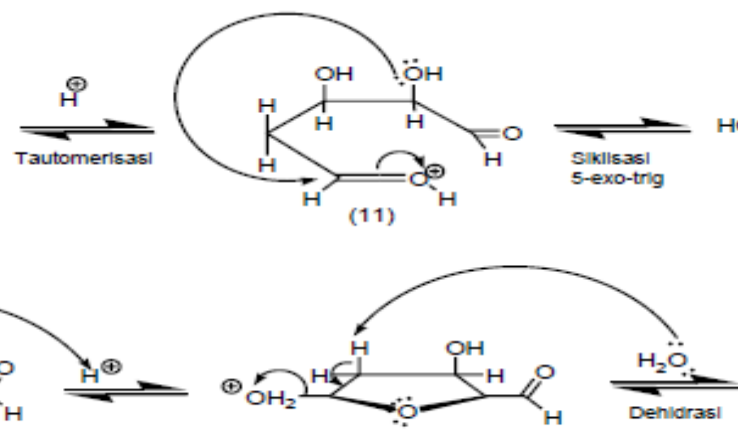

(14)

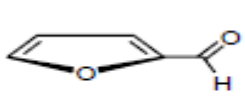

(1)

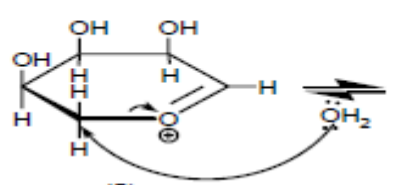

(5)

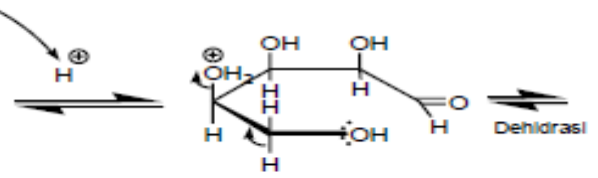

(9)
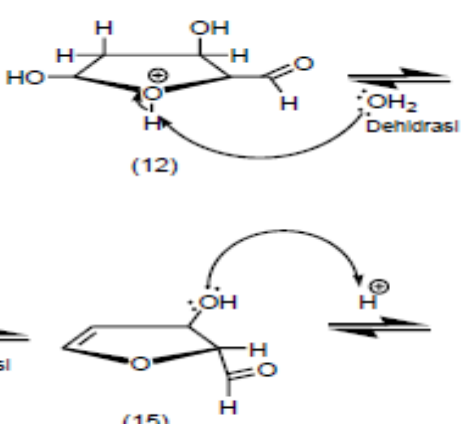

(15)

Gambar 8. Mekanisme reaksi dehidrasi pentosa menjadi furfural

(7) mengalami deprotonasi lanjutan oleh asam menjadi polialkohol (8), selanjutnya mengalami proses yang sama yaitu berturut- turut mengalami deprotonasi oleh asam diikuti dengan dehidrasi menjadi (10). Selanjutnya (10) yang bertautomerisasi 
dengan karbonium (11) segera mengalami siklisasi 5-exo-trig (Baldwin rules) menjadi (12). Setelah mengalami deprotonasi dengan bantuan air menjadi (13) yang diikuti dehidrasi alkohol (14) dan (16) hingga menghasilkan pembentukan cincin aromatik furfural (1).

\section{Pembuatan Furfural Metode Destilasi}

Pembuatan furfural dilakukan menggunakan metode destilasi dikarenakan hasil yang diperoleh pada metode sebelumnya kurang memuaskan. Hasil yang diperoleh dengan metode destilasi yaitu furfural murni yang bebas dari pengotor seperti katalis asam, air dan ion pengotor lainnya. Hidrolisis furfural dari tempurung kemiri menghasilkan rendemen $0,9 \%$. Rendahnya rendemen ini dipengaruhi oleh kadar pentosan dalam tempurung kemiri yang sangat kecil yaitu $14,55 \%$. Konfirmasi berhasilnya pembuatan furfural diperoleh dari hasil analisis FTIR dan GC-MS yang sesuai. Analisis dengan Spektrofotometer Fourier Transform-Infra Red (FTIR) ditunjukkan dalam spektra yang dapat dilihat pada Gambar 9.

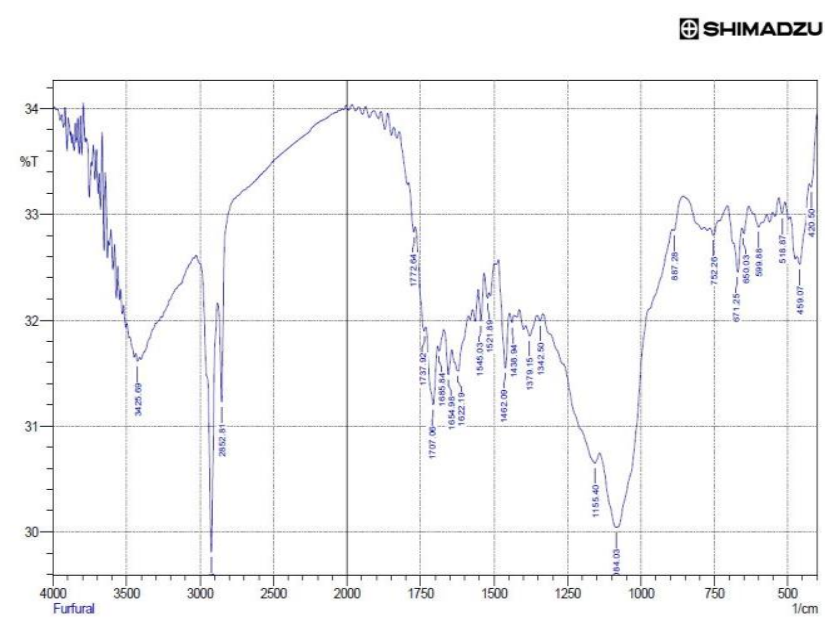

Gambar 9. Spektrum IR furfural hasil hidrolisis
Interpretasi data spektrum IR furfural dibandingkan dengan referensi yang dapat dilihat pada Tabel 1 dengan tujuan melihat adanya gugus - gugus fungsi furfural dalam sampel yang sesuai dengan furfural teoritis.

Spektrum IR pada Gambar 9 dan Tabel 1 menunjukkan bahwa terdapat serapan dengan intensitas sedang di daerah 1707,06 $\mathrm{cm}^{-1}$ yang merupakan regangan $\mathrm{C}=\mathrm{O}$ gugus fungsi karbonil, tetapi puncak ini dapat juga muncul untuk senyawa kimia, seperti asam karboksilat (COOH), keton (RCOR), dan ester (RCOOR), akan tetapi kehadiran aldehida pada senyawa ini lebih spesifik ditunjukkan dengan serapan pada daerah sekitar 2852,81 cm dan 2924,18 $\mathrm{cm}^{-1}$. Serapan pada daerah 3425,69 $\mathrm{cm}^{-1}$ menunjukkan adanya gugus $\mathrm{OH}$. Gugus $\mathrm{OH}$ sebagai pengotor dalam sampel berasal dari proses penguapan yang tidak sempurna.

Adanya serapan dengan intensitas lemah pada daerah $1521,89 \mathrm{~cm}^{-1}$ dan $1622,19 \mathrm{~cm}^{-1}$ akibat regangan $\mathrm{C}=\mathrm{C} \quad \mathrm{sp}^{2}$ menunjukkan senyawa tersebut adalah senyawa aromatik. Serapan kuat pada daerah $2924,18 \mathrm{~cm}^{-1}$ menunjukkan adanya gugus $\mathrm{C}-\mathrm{H}$ aromatik dan diperjelas dengan serapan pada daerah luar bidang $887,28 \mathrm{~cm}^{-1}$ yang menunjukkan adanya ikatan C-H cincin (Lerrick, 2010). Puncak vibrasi ulur pada daerah sekitar 1155,40 $\mathrm{cm}^{-1}$ menunjukkan adanya ikatan C-O-C dalam struktur molekul furfural.

Furfural yang diperoleh selanjutnya dianalisis GC-MS untuk memperkuat data FTIR. Puncak tertinggi data GC-MS menunjukkan adanya furfural. 
Tabel 1. Perbandingan bilangan gelombang furfural hasil hidrolisis dengan referansi Sastrohamidjojo, H. (1992)

\begin{tabular}{|c|c|c|c|c|c|c|}
\hline \multirow{2}{*}{ Vibrasi } & Str C-H & Str C-H & Str C=O & Str C=C & Str C-O & Str O-H \\
\cline { 2 - 5 } & Aromatis & Aldehid & Aldehid & Aromatis & Tidak ada \\
\hline Teoritis & $\sim 3100-3000$ & $\sim 2870-2750$ & $\sim 1820-1620$ & $\sim 1650-1450$ & $\sim 1300-1110$ & Tid \\
\hline $\begin{array}{c}\text { Furfural } \\
\text { hasil } \\
\text { hidrolisis }\end{array}$ & 2924,18 & 2852,81 & 1707,06 & 1521,89 & 1184,03 & 3425,69 \\
\hline
\end{tabular}

Identifikasi sampel menggunakan GC-MS dilakukan untuk konfirmasi senyawa target dan juga untuk mengetahui kemurnian senyawa furfural hasil hidrolisis. Analisis senyawa furfural dilakukan terhadap puncakpuncak fragmentasi yang selanjutnya dapat diidentifikasi sebagai senyawa furfural berdasarkan indeks kemiripan terhadap senyawa standar. Hasil analisis GC ditunjukkan pada Gambar 10.
Senyawa puncak 1 dengan spektra referensi dapat dipastikan bahwa senyawa tersebut adalah furfural atau furfurufaldehid (indeks kemiripan : 97\%). Disamping itu, juga terlihat puncak isotop ${ }^{2} \mathrm{H}$ yang setara dengan berat molekul (BM) 97 yang dapat dilihat pada Gambar 11. Puncak ini dapat dikenali melalui perbandingan intensitas \% kelimpahan puncak $\mathrm{m} / \mathrm{z} 97$ terhadap puncak m/z 96. Hal ini bersesuaian dengan perbandingan kelimpahan isotop $\mathrm{H}$ di alam sebagai ${ }^{1} \mathrm{H}:{ }^{2} \mathrm{H}$ $=99,98 \%: 0,01 \%$.

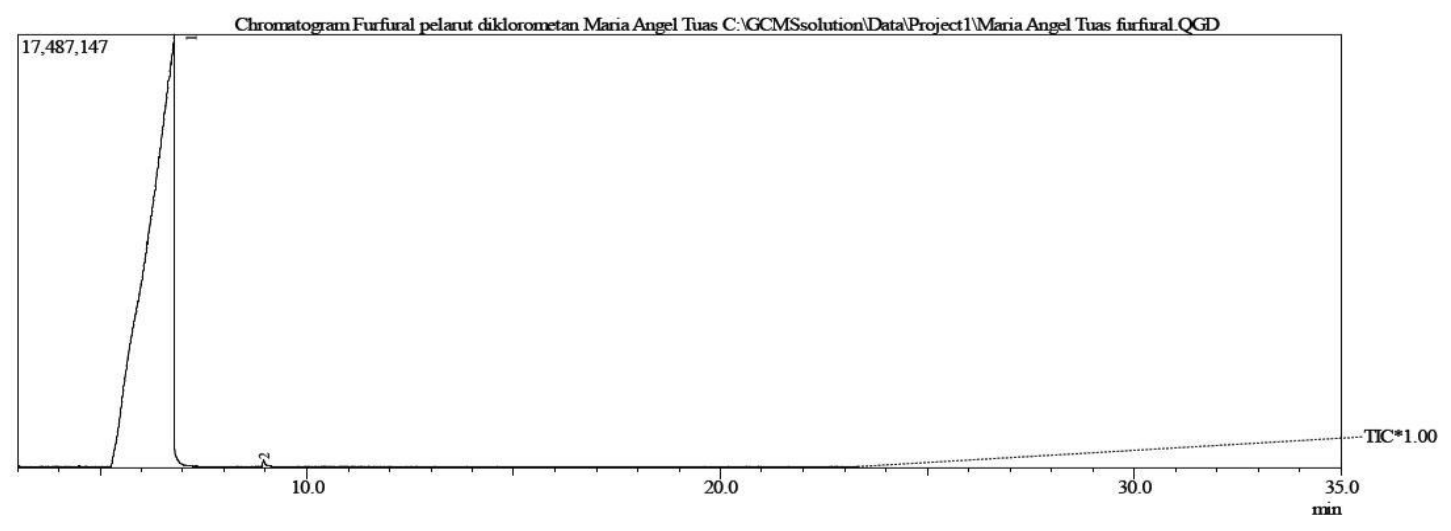

Gambar 10. Kromatogram furfural hasil hidrolisis 


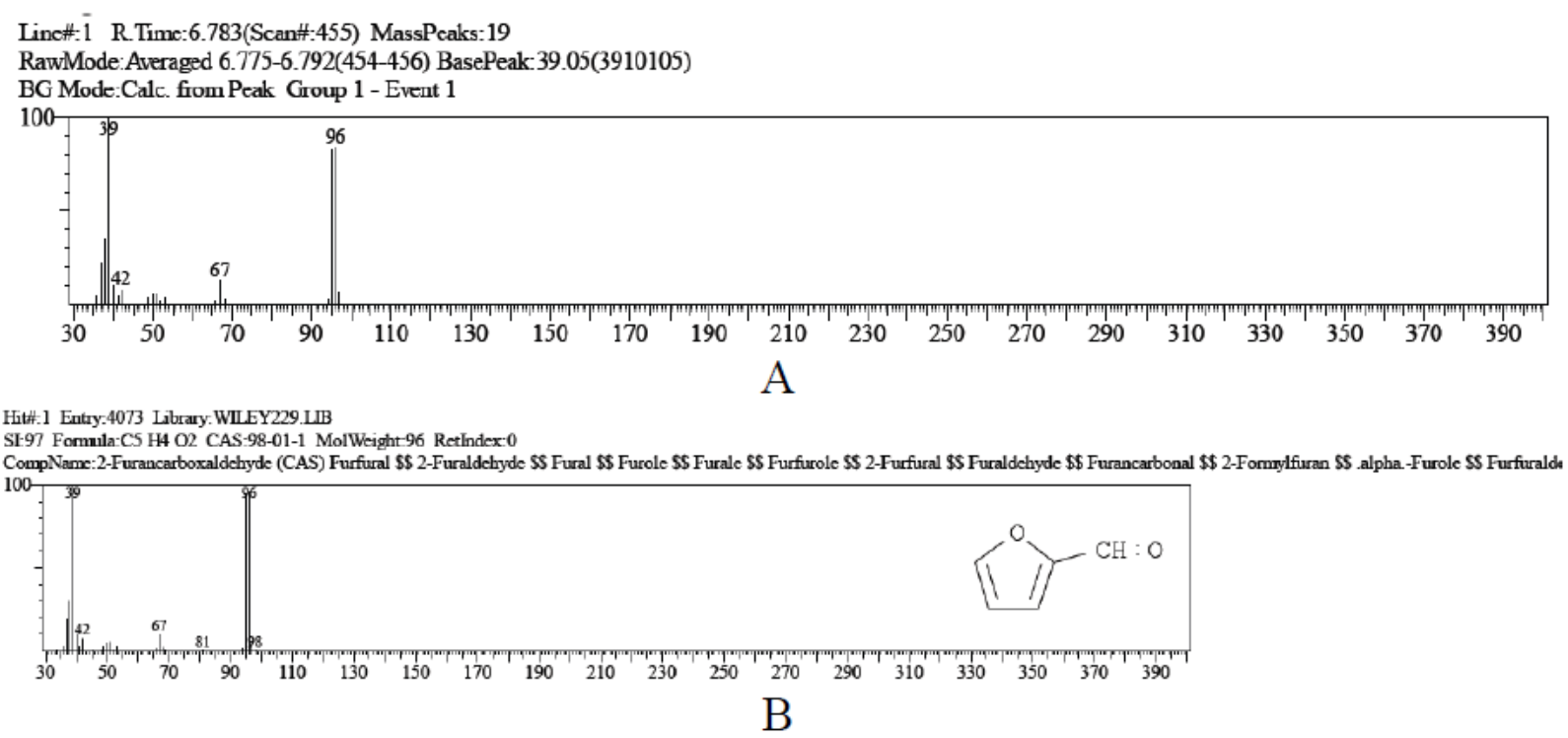

Gambar 11. (A) Spektra MS puncak 1 furfural hasil hidrolisis (B) spektra senyawa referensi

Analisis GC-MS menghasilkan dua puncak spektra yang mengindikasikan adanya dua senyawa yang terdapat dalam sampel furfural. Kromatogram GC-MS pada Gambar 10 dapat diuraikan dalam Tabel 2.

Tabel 2 Jenis dan komposisi senyawa dalam furfural hasil hidrolisis

\begin{tabular}{ccccc}
\hline Puncak & $\begin{array}{c}\text { Waktu } \\
\text { retensi } \\
\text { (menit) }\end{array}$ & $\begin{array}{c}\text { Luas } \\
\text { puncak } \\
(\%)\end{array}$ & Senyawa & SI \\
\hline 1 & 6.788 & 99,88 & Furfural & 97 \\
2 & 8.958 & 0,12 & Metiffurfural & 95 \\
\hline
\end{tabular}

Gambar 10 dan Tabel 2 memperlihatkan bahwa kedua senyawa tersebut memiliki perbedaan kadar yang sangat besar, baik dalam kuantitas maupun keterpisahan (Rt). Puncak yang tertinggi adalah puncak ke-1 dengan persentase sebesar 99,88\%. Puncak 1 dengan waktu retensi 6.783 menit memberikan puncak-puncak dengan nilai $\mathrm{m} / \mathrm{z}$ : 96, 67, 42, 39. Berdasarkan perbandingan berat molekul (BM) dan waktu retensi spektra massa senyawa puncak 1 dengan spektra referensi dapat dipastikan bahwa senyawa tersebut adalah furfural atau furfurufaldehid (indeks kemiripan: 97\%). Fragmen-fragmen senyawa furfural yang terbentuk ditampilkan pada Gambar 12.

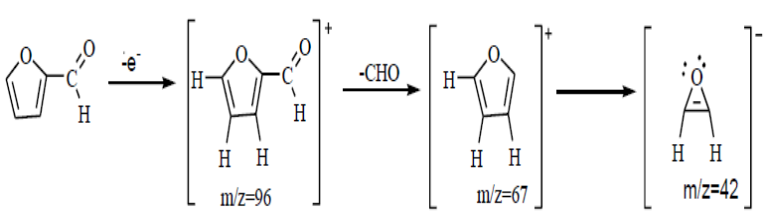

Gambar 12. Mekanisme fragmentasi senyawa furfural

Puncak ion molekul pada $\mathrm{m} / \mathrm{z} 96$ yang merupakan massa molekul furfural. Sebuah puncak ion pada m/z 67 menunjukkan pembentukan molekul $\mathrm{C}_{4} \mathrm{H}_{3} \mathrm{O}^{-}$akibat lepasnya - $\mathrm{CHO}$ dan sebuah puncak ion pada $\mathrm{m} / \mathrm{z} 42$ yang merupakan $\mathrm{C}_{2} \mathrm{H}_{2} \mathrm{O}$. Hasil analisis yang diperoleh dari GC-MS dan didukung dengan adanya data FTIR maka dapat dikatakan bahwa hasil yang diperoleh adalah furfural dengan kemurnian sebesar 99,88\%.

\section{KESIMPULAN}

Furfural dengan kemurnian 99,88\% dapat dihasilkan dari limbah tempurung kemiri melalui tahap hidrolisis dan dehidrasi dengan menggunakan metode destilasi. Hasil analisis 
GC-MS membuktikan adanya senyawa furfural dan didukung dengan data FTIR yang menunjukkan gugus fungsi dari senyawa furfural. Rendemen yang diperoleh sebesar $0,9 \%$ pada kondisi optimum 5 jam pemanasan dengan penggunaan asam sulfat $30 \%$.

\section{DAFTAR PUSTAKA}

Andaka, G. (2013). Optimasi Konsentrasi Asam Sulfat dan Kecepatan Pengadukan pada Proses Hidrolisis Ampas Tebu menjadi Furfural, Jurnal Teknologi Technoscientia, 5 (2), hal:52-161.

Fadjarwati, D., dan Susanto, H. (2005). Penghematan Konsumsi Katalis dalam Proses Hidrolisis Tandan Kosong Sawit untuk Produksi Furfural, Jurnal Teknik Kimia Indonesia, 4 (3), hal:279-286.

Fessenden, R.J., dan Fessenden, J.S. (1986). Kimia Organik Edisi ke-3, Terjemahan Aloysius H. Pujaatmaka, Jakarta, Erlangga.

Hidajati, N. (2006). The Treatment of the Corn-Knob as A Raw Material for Making Furfural, Jurnal Ilmu Dasar, Jurusan Kimia FMIPA, Universitas Negeri Surabaya, Surabaya.

Juwita,R., Syarif, L.R., dan Tuhuloula, A. (2012). Pengaruh Jenis dan Konsentrasi Katalisator Asam Terhadap Sintesis Furfural dari Sekam Padi, Jurnal Fakultas Teknik, Universitas Lambung Mangkurat, 1 (1), hal:34-38.

Kimbal, J.W. (1988). Biologi, Jakarta, Erlangga.

Lempang, M., Wasrin,S., dan Gustan, P. (2011). Struktur dan Komponen Arang serta Arang Aktif Tempurung Kemiri,
Pusat Penelitian dan Pengembangan

Keteknikan Kehutanan dan Pengolahan Hasil Hutan, Bogor.

Lerrick, R.I. (2010). Bahan Ajar Mandiri Penentuan Struktur Senyawa Organik, Jurusan Kimia, Fakultas Sains dan Teknik, UNDANA, Kupang.

Mulyati, S., dan Umi, F. (2008). Pemanfaatan Limbah Sekam Padi sebagai Bahan Baku Furfural, Hasil Penelitian Industri, hal 1-6.

Nalle, T. (2013). Identifikasi Furfural Hasil Hidrolisis Asam dari Sabut dan Kulit Buah Pohon Lontar (Borassus sundaicus) Asal Pulau Timor, Fakultas Sains dan Teknik, Universitas Nusa Cendana, Kupang.

Panturau, J.M. (1987). By Products of Cane Sugar Industry. An Introduction to their Industrial Utilization, El Sevier Publishing Co. The Netherland.

Sastrohamidjojo, H. (1992). Spektroskopi Inframerah. Yogjakarta, Liberti:Yogjakarta. Setyadji, M. (2007). Hidrolisis Pentosan menjadi Furfural dengan Katalisator Asam Sulfat untuk Meningkatkan Kualitas Bahan Bakar Mesin Diesel, Prosiding PPI-PDIPTN, Batan Yogyakarta.

Tefi, I. (2015). Penentuan Hasil Hidrolisis Furfural Optimum dari Tumbuhan Alang-alang (Imperata cylindrica) Berdasarkan Variasi Perbandingan Substrat dan $\mathrm{H}_{2} \mathrm{SO}_{4}$, Lama Waktu Pemanasan dan Konsentrasi $\mathrm{H}_{2} \mathrm{SO}_{4}$, Jurusan Kimia, Fakultas Sains dan Teknik, Universitas Nusa Cendana, Kupang.

Winaputri, M. G. N. (2014). Prarancangan Pabrik Furfural dari Tandan Kosong 
86 Jurnal Purifikasi, Vol. 17, No. 2, Juli 2017: 77-86

Kelapa Sawit Kapasitas 20.000

ton/tahun, Jurusan Teknik Kimia,

Universitas Sebelas Maret, Surakarta 